\title{
The Libel Suit in Retrospect: What Plaintiffs Want and What Plaintiffs Get
}

\author{
Randall P. Bezanson $\dagger$
}

Ironies abound in libel law. Most libel suits fail, yet suits persist. Constitutional privileges present onerous obstacles to success in public cases, yet public plaintiffs continue to sue. Litigation is prolonged and expensive, yet plaintiffs continue to carry suits to trial. Finally, while the law of libel is supposed to protect reputation, "[t]lie few plaintiffs who succeed resemble the remnants of an army platoon caught in an enemy crossfire."1

These ironies prompted Professors Gilbert Cranberg and Jolin Soloski, both of the School of Journalism at the University of Iowa, and me to begin the Iowa Libel Research Project. Our objective has been to probe beneath the surface of libel suits to better understand the dynamics of the libel dispute and the actions and inotivations of the parties to it. Following Marc Franklin's important groundbreaking work, ${ }^{2}$ we undertook a detailed analysis of the libel litigation process as a whole, from the appearance of the allegedly libelous story, through discussions between plaintiff and attorney, to the outcome of the case. We were particularly interested in examining why plaintiffs sue and what the media can do to prevent suit. We also wanted to know how plaintiffs and defendants feel about the disputed stories, the nredia, and their experience with litigation. Our ultimate objective has been to assess and test the susceptibility of libel disputes to nonjudicial forms of resolution.

We based our libel litigation study on a wide variety of sources. First, we analyzed and coded virtually all cases between 1974 and 1984 with a reported opinion or order in which a libel or privacy clain was the principal or a major legal theory. Second, we supplemented these cases

$\dagger$ Professor of Law, University of Iowa College of Law. B.S. 1968, Northwestern University; J.D. 1971, University of Iowa. This article is drawn from a chapter in a forthcoming book, Libel Law and the Press: Myth and Reality, to be published by The Free Press Division of MacMillan, Inc. (forthcoming 1987), coauthored by me and Professors Cranberg and Soloski of the University of Iowa School of Journalism. The book represents the completion of Phase I of the Iowa Libel Research Project.

1. R. SACK, Libel, Slander, and Related Problems at xxvi (1980).

2. Franklin, Suing the Media for Libel: A Litigation Study, 1981 AM. B. Found. RES. J. 455; Franklin, Winners and Losers and Why: A Study of Defamation Litigation, 1980 AM. B. Found. RES. J. 797. 
with a limited population of case files and a larger population of claim codings that a media-libel insurer provided, nost of which were settled or litigated without reported judicial action. Third, we selected 164 cases involving hibel claims against inedia from these two groups, and conducted extensive structured interviews with the plaintiffs. Fourth, we interviewed the media defendants in each case for which a plaintiff was interviewed, and also interviewed personnel at all pertinent levels of selected newspapers. We obtained additional data from plaintiffs' lawyers, inedia lawyers, and a survey of over 170 newspapers to determine rates of suit, liability, and settlement.

This Article explores only a small portion of the larger study. It will focus on the plamtiffs' retrospective attitudes toward libel litigation in order to understand the function of suit from the plaintiffs' perspective and to assess the plaintiffs' amenabihty to resolution of the dispute through alternative processes. Analysis of these issues will draw primarily upon the information we obtained from the media-libel plaintiffs we surveyed. It will focus largely on the actions and objectives of plaintiffs who actually sued and whose cases generated a reported judicial decision. While these plaintiffs appear to exhibit similar characteristics to the broader population of plaintiffs who bring suit against media defendants and seriously pursue their claim in litigation, a full discussion of the findings for this larger population of plaintiffs and claimants is beyond the scope of this Article. ${ }^{3}$

\section{I}

RETROSPECTIVE VIEWS OF LITIGATION: What Litigation ACHIEVES

Most plaintiffs lost in court. ${ }^{4}$ Even for those who won, the terms of

3. The 164 plaintiff-interview cases included 12 cases we drew from insurance company files that plaintiffs either settled or dropped with no further action beyond the filing of the claim. Plaintiff responses in this subgroup closely parallel those of the remaining plaintiffs. Information provided from a variety of sources, including the case histories of over 1300 insurance claims, suggests that the incidence of settlement activity in libel cases is much lower than for civil litigation in general. Perhaps $25 \%$ of libel claims involve some form of negotiated resolution, although only a small proportion-perhaps 10\%-involve financial settlement. See D. Trubek, J. Grossman, W. Felstiner, H. Kritzer \& A. SArat, 1 Civil litigation Research Project Final Report, S20, S23 (1983). The discussion of plaintiff objectives and attitudes in this Article is limited to the population of seriously litigated libel actions against media defendants that generated published judicial orders or opinions on any issue arising in the litigation, whether or not dispositive of the libel claim. For some of the responses reported in this Article, one might expect different attitudes to prevail among plaintiffs who did not sue, or who settled. The forthcoming report of the Iowa Libel Research Project will further explore this subject.

Unless indicated otherwise, statistical relationships discussed in this article are significant within the .05 level of confidence.

4. The plaintiff rate of success by judgment in reported cases was about 10\%. The rate of plaintiff success by judgment is even lower when including those cases that are not reported but that 
judicial victory were disappointing. Successful litigants obtained an average of $\$ 80,000$ in damage awards. ${ }^{5}$ Excluding two large awards, however, the average recovery was only $\$ 20,600$, a sizeable portion of which went to fees and costs. Plaintiffs who settled their claims obtained an average of $\$ 7,000$, which also must be reduced for fees and costs. ${ }^{6}$ By most standards, plaintiffs' financial victories were of modest proportions.

Why, then, do plaintiffs persist in pursuing tibel actions? Earlier published reports of the Iowa Libel Research Project have suggested that the principal object of the lawsuit for most plaimtiffs is not to obtain monetary rehef for financial harm. ${ }^{7}$ Instead, the major motivating factors are restoring reputation, correcting what plaintiffs view as falsity, and vengeance. ${ }^{8}$ We have also suggested that ultimate judicial victory should not be the primary criterion for judging success, since the plaimtiffs' motives in filing suit inay often make that criterion largely irrelevant. Instead, plaintiffs view the lawsuit as an instrument for self-help, regardless of its judicial outcome. ${ }^{9}$ To them, the hibel suit represents an official engagement of the judicial system on their behalf, and the act of suing represents a legitimation of their claims of falsehood. Indeed, inany plaintiffs may beheve they have no other means of recourse, and therefore feel that litigation is the only way to set the record straight.

The conclusion in our previous reports, that noninonetary motives dominate the decision to sue, has been based principally on analyses of the plaintiffs' actions leading to suit, the harm they perceive, their motivations for suing, the context in which they seek legal advice, the role of the lawyer, and the reasons they give for suit. ${ }^{10}$ Plaintiffs-particularly

resulted in notification of the insurer, although the incidence of settleinent grows with inclusion of these cases.

5. Plaintiff "wins" include only those judgments that were final, that is, not reversed on appeal or still pending on appeal. In the 13 instances of plaintiff judicial victory (out of the 164 surveyed plaintiffs) the awards were as follows:

Plaintiff $1 \ldots \ldots \ldots \ldots \ldots \ldots \ldots . \$ 15,000$

Plaintiff $2 \ldots \ldots \ldots \ldots \ldots \ldots \ldots . \$ 30,000$

Plaintiff $3 \ldots \ldots \ldots \ldots \ldots \ldots \ldots . \$ 45,000$

Plaintiff $4 \ldots \ldots \ldots \ldots \ldots \ldots \ldots \ldots$ \$ 3,000

Plaintiff $5 \ldots \ldots \ldots \ldots \ldots \ldots \ldots \ldots . \$ \ldots 222,000$

Plaintiff $6 \ldots \ldots \ldots \ldots \ldots \ldots \ldots \$ \$ \$ 490,000$

Plaintiff $7 \ldots \ldots \ldots \ldots \ldots \ldots \ldots \$ \$ 75,000$

Plaintiff $8 \ldots \ldots \ldots \ldots \ldots \ldots \ldots . \$ \$ 30,000$

Plaintiff $9 \ldots \ldots \ldots \ldots \ldots \ldots \ldots . \$ 50,000$

Plaintiff $10 \ldots \ldots \ldots \ldots \ldots \ldots \ldots,-0$ -

Plaintiff $11 \ldots \ldots \ldots \ldots \ldots \ldots \ldots, 0$ -

Plaintiff $12 \ldots \ldots \ldots \ldots \ldots \ldots,-0$.

unknown

\section{Average award (excluding plaintiff 13$) \ldots \ldots \ldots \ldots \ldots \ldots 80,000$}

Zero dollar awards represent judgments for plaintiffs, with costs assessed, but without money damage awards.

6. The settlement ainounts ranged froin $\$ 300$ to $\$ 18,000$.

7. See Bezanson, Libel Law and the Realities of Libel Litigation: Setting the Record Straight, 71 IowA L. REv. 226, 228 (1985). Roughly $20 \%$ of the surveyed plaintiffs-largely the private plaintiffs-appear to have sued to obtain money as coinpensation for actual material econounic harm from the alleged libel.

8. Id.

9. Id.

10. The findings, which are only summarized here, are thoroughly developed in our 
public plaintiffs - often contact the inedia before they contact a lawyer. The media response is usually offensive to the plaintiffs, who report being angered by the inedia's indifference, arrogance, or insensitivity, and the plaintiffs' reactions appear to be a significant factor in their decision to sue. Plaintiffs express their harm in largely nonfinancial terms, and appear to engage a lawyer (usually on some form of contingency) already having decided to sue. Plaintiffs, particularly in pubtic cases, hire lawyers specifically to bring suit. The influence of the lawyer on the plaintiffs' decision to sue is shght. Plaintiffs view the filing of suit itself as achieving meamingful vindication.

In significant respects, media defendants confirm this picture of plaintiffs' actions and motivations. Defendants indicated that between one-third and one-half of hbel-type complaints have validity, that a majority of plaintiffs seek vindication and punishment rather than conpensation for real economic loss, and that media organizations respond poorly to complaints. ${ }^{11}$

The drainatic odds against winning that libel plaintiffs often knowingly face in hitigation suggest that inotivations other than financial gain or formal victory often dominate the decision to sue. We obtained information on these inotives and objectives froin plaintiffs in a series of questions seeking their retrospective views of the litigation process. This Article will report and analyze the plaintiffs' responses to these questions. ${ }^{12}$ The responses were self-reported and therefore subject to possible bias. For that reason, the analysis focuses on what the responses reveal about the general attitudes and notivations of plaintiffs. It does not necessarily follow that the responses are accurate predictions of future plaintiff conduct.

forthcoming book. Some have been noted previously in Bezanson, Cranberg \& Soloski, Libel Law and the Press: Setting the Record Straight, 71 Iowa L. REv. 215 (1985). Other findings have been reported in The Libel Litigation Process, Address by Professor Randall P. Bezanson delivered at the College of William \& Mary (June 5, 1986) (unpublished manuscript on file with author), and in The Economics of Libel: An Empirical Assessment, Address by Professor Randall P. Bezanson delivered at the Gannett Center for Media Studies, Columbia University (June 13, 1986) (unpublished manuscript by Bezanson, Cranberg, and Soloski on file with author) (to appear in The Economics of Libel, forthcoming 1987, Columbia University Press). Both addresses are based on portions of R. Bezanson, G. Cranberg \& J. Soloski, Libel Law and the Press: Myth and Reality (forthcoming 1987, The Free Press Division of MacMillan, Inc.).

11. See Cranberg, Fanning the Fire: The Media's Role in Libel Litigation, 71 IowA L. REv. 221 (1985).

12. The plaintiff responses are both retrospective and attitudinal, and therefore uniquely subject to error or bias. While caution in interpretation and generalization is therefore warranted, we are of the view that the information is, on the whole, important and reliable. We base this conclusion on two factors. First, the plaintiffs' attitudinal responses are internally consistent with a wide variety of other attitudinal and factual information we collected in the study. Second, plaintiff responses yielded internal patterns of consistency among plaintiff subgroups (such as public officials in contrast to persons employed in the private sector) which make error or bias less likely. 
The responses analyzed in this Article involve only one part of an extensive set of questions. The specific purpose of the questions discussed here was to obtain a retrospective view of the litigation experience from the plaintiffs' perspective and to explore the plaintiffs' general receptivity to nonlitigation processes for resolution of their libel dispute. We first asked plaintiffs whether the lawsuit accomplished anything and, if so, what it accomplished. We also explored the plaintiffs' degree of satisfaction with the hitigation process and the specific nature of the plaintiffs' satisfaction or dissatisfaction. We asked each plaintiff whether, knowing what had transpired, he or she would do anything differently if faced with a similar situation. Finally, we asked each plaintiff whether alternative forms of nonjudicial resolution would be acceptable or preferable to suit and under what preconditions each plaintiff would be willing to employ such alternatives.

The analysis of these responses in this Article yields some clear conclusions. Judicial success is not the sole measure by which plaintiffs judge the utility of the lawsuit. Indeed, the judicial process frustrates many plaintiffs. Yet virtually all plaintiffs report that they would sue again if faced with a similar situation. Thus, plaintiffs feel they have accomphished something simply by suing-even if they are later unsuccessful. Most plaintiffs would welcome nonjudicial alternatives, but only if the oppportunity for public vindication of their interest in reputation could be assured. In sum, plaintiffs view the lawsuit as a form of public vindication, and they will not employ alternatives unless these alternatives provide an appropriate vehicle for pursuing that prinary objective.

\section{A. What the Lawsuit Accomplished}

In order to ascertain the plaintiffs' attitudes about the lawsuit and the objectives they had set for it, we explored their feelings about what the lawsuit accomplished. Of particular interest were the perceptions of the plaintiffs who lost their lawsuits. Sixty-seven of 106 losing plaintiffs (63\%) responded that the lawsuit liad accomplished something. ${ }^{13}$ These plaintiffs felt that the lawsuit served some positive and constructive purpose unrelated to its judicial resolution and despite their failure to obtain any form of financial reward. If we presume that the breakdown of pending cases ${ }^{14}$ will generally mirror those finally resolved, and if we add the thirteen cases won or settled by plaintiffs, it appears that in roughly two-

13. Fifty-eight of the 67 losing plaintiffs who felt the lawsuit accomplished something provided a specific explanation of what was accomplished. Even using this lower number (58 of 106 plaintiffs who lost, or $55 \%$ ) and adding the 22 plaintiffs who won or settled, the most conservative estimate would provide that 80 of 130 , or $62 \%$ of all plaintiffs whose cases were completed, felt the suit accomplished something, while only $10 \%$ won.

14. Roughly one-fifth of the plaintiff-interview cases were pending at the time of the surveyeither on appeal, proceeding to trial after pretrial action on privilege issues, or on remand. 
thirds of the cases the lawsuit achieved some of the plaintiffs' objectives, even though $86 \%$ of the plaintiffs lost in court.

We then asked the losing plaintiffs who felt the lawsuit accomplished something what they felt it accomplished. Their responses appear below in Table One.

\section{TABLE ONE ${ }^{15}$}

What Was Accomplished Despite Loss

Response

Reputation Defended

Support from Family and Friends

Further Publicity Stopped

Media Pumshed

\begin{tabular}{|c|c|}
\hline Number & Percent \\
\hline 24 & $41 \%$ \\
\hline 5 & $9 \%$ \\
\hline 23 & $40 \%$ \\
\hline 6 & $10 \%$ \\
\hline
\end{tabular}

The most significant aspect of the plaintiffs' responses is their consistency with the conclusions mentioned earlier about the reasons why plaintiffs sue. ${ }^{16}$ Forty-one percent of the losing plaintiffs felt that the lawsuit served to defend their reputation. An additional $40 \%$ of the plaintiffs beheved that the suit effectively deterred or halted further pubhication, which thus protected their reputational interests. Another 9\% responded that the lawsuit, although unsuccessful, achieved support from family and friends - the very groups with whoin plaintiffs' reputational interests are often most acute. Combining these three responses, $90 \%$ of the losing plaintiffs who said that the lawsuit accoinplished something, and $48 \%$ of all losing plaintiffs, stated that the lawsuit achieved reputation-related objectives. ${ }^{17}$

The great preponderance of reputation-related responses is consistent with the conclusion drawn from other responses, that for most plaintiffs the primary interest in suing was rectification of claimed falsity, not money. ${ }^{18}$ Only $10 \%$ of the plaintiffs who lost but indicated that the suit had achieved something stated that their goal had been punishment of the media. Pumshinent and money seem-in retrospect, at least-to have played a relatively minor role in the interests of the plaintiffs who said that the lawsuit accomplished something.

However, money and punishment may have played a greater role as

15. Table One excludes all pending cases.

16. See supra text accompanying notes 7-9.

17. This does not include those whose responses were uncodable, or those who did not specifically respond when asked what the suit accomplished, but who had indicated that, while the defendant won, the suit accomplished something. See supra note 13. Reputation was a likely factor for some of these plaintiffs as well.

18. A variety of other responses and data, to be reported in the full study, are consistent with this conciusion. 
motivating factors for the $37 \%$ of losing plamtiffs who felt that the lawsuit accomplished nothing. The disappointed losing plaintiffs consisted disproportionately of the plaintiffs with low community visibility who sued for money and whose loss therefore often took a more direct economic form. By contrast, the population of losing plamtiffs who felt something liad been accoinplished consisted disproportionately of highly visible, public plaintiffs who tended to sue to protect their reputations, not for money. It is iromic that the public plaintiffs, whose suits are most constrained by constitutional privileges, ${ }^{19}$ express the higliest degree of satisfaction with litigation, even when their suits are unsuccessful.

\section{B. Plaintiff Satisfaction with Litigation}

We also asked plaintiffs general and specific questions about tleir feelings regarding the litigation experience. These questions enabled us to exalnine plaintiff attitudes concerning the litigation process imdependent of the plaintiffs' personal objectives in brimging suit. We surveyed all plaintiffs, not just tliose who lost.

Of 151 plaintiffs, fifty-two, or 34\%, expressed satisfaction with their litigation experience. An additional fifty-two plaintiffs (34\%) expressed dissatisfaction, and forty-seven plaintiffs (31\%) expressed extreme dissatisfaction. Roughly two-thirds of the plaintiffs thus expressed dissatisfaction. Many (56\%) of these plaintiffs caine from the group, comprising $66 \%$ of all plaintiffs, who won, settled, or lost but felt the suit accomplished something.

Closer examination of the responses reveals the reason for the apparent disjunction between perceived accomplislıments of the suit and feelings of dissatisfaction with litigation. The plaimtiffs' specific comments about their litigation experiences follow in Table Two.

\section{TABLE Two}

COMMENTS ABOUt LITIGATION EXPERIENCE

$\begin{array}{lcrr}\text { Response } & \text { Number } & & \text { Percent } \\ \text { Valuable Experience, Goals Met } & 39 & & 25 \% \\ \text { Angry and Bitter } & 13 & 8 \% \\ \text { Critical of Media } & 6 & 4 \% \\ \text { Critical of Media and Judicial System } & 34 & 22 \% \\ \text { Critical of Judicial Power } & 44 & 28 \% \\ \text { Other } & 20 & 13 \%\end{array}$

The plaintiffs' dissatisfaction seens related to their frustration witl the unresponsiveness of the judicial systein to their claimed liarm. Under

19. See Gertz v. Robert Welch, Inc., 418 U.S. 323 (1974); note 24 infra. 
this interpretation, it is consistent for inany plaintiffs to feel that the lawsuit accoinplished soine of their objectives, yet to express dissatisfaction with the legal systein's failure to recognize those objectives and formally respond to thein. These plaintiffs appear to feel that while the lawsuit itself serves their reputational objectives, the formal legal system often does not. The plaintiff's overwhelming retrospective sense of dissatisfaction and bitterness toward the judicial systein supports this interpretation. A inajor inotivating factor in the plaintiffs' initial decision to sue was their anger at the inedia, often compounded by the perceived arrogance or ineptitude of the media in responding to their contact with the media following publication. Reinarkably, the plaintiffs' sense of anger and frustration radically shifted by the end of the litigation process from the inedia to the judicial system. Of the plaintiffs expressing dissatisfaction, $67 \%$ direct it in whole or in part toward the judicial system. ${ }^{20}$ This strongly suggests that a disjunction exists between the plaintiffs' objectives-some of which are achieved despite the formal judicial outcoineand the rules and results of the judicial process. It also suggests that this disjunction is a source of great frustration among plaintiffs.

\section{Plaintiffs' Satisfaction with Their Course of Action}

As a final measure of the plaintiffs' objectives and inotivations, we asked the plamtiffs what they would do differently if faced again with a similar situation, knowing their actual experience. The responses appear below in Table Three.

\section{TABLE THREe}

Plaintiff Action if Faced with Same

SitUATION AGAIN ${ }^{21}$

\begin{tabular}{|c|c|c|}
\hline & & $\begin{array}{l}\text { Percent } \\
\text { Specific }\end{array}$ \\
\hline Response & Number & Response \\
\hline Not Sue & 7 & $5.5 \%$ \\
\hline Pursue Nonlitigation Alternative & 10 & $8.0 \%$ \\
\hline Sue Again & 87 & $68.5 \%$ \\
\hline Sue, with better lawyer & 16 & $12.5 \%$ \\
\hline Sue, exert more control & 7 & $5.5 \%$ \\
\hline
\end{tabular}

The table indicates that libel plaintiffs are wedded to litigation as the

20. This statistic includes plaintiffs whose responses were coded as "other." Interestingly, a higher proportion (75\%) of the private plaintiffs expressed bitterness toward the judicial process than did public plaintiffs (60\%) (excluding corporate plaiutiffs).

21. The exact question asked was: "Now that the suit is over, if you were faced with a similar situation, what would you do differently, if anything?" 
single inost effective ineans of achieving vindication of their reputation. Even after the experience of hitigation, in which most plaintiffs lost and toward which most plaintiffs express dissatisfaction, $86.5 \%$ of the plaintiffs who specifically responded to the question stated that they would sue again if faced with a similar situation. Absent an alternative process, 95\% of the plaintiffs stated that they would sue again. This proportion holds for those plaintiffs who lost. Indeed, nearly $80 \%$ of the plaintiffs who lost and said the suit accomphished nothing indicated that they would sue again, although $40 \%$ of them would do so only after engaging a different lawyer or exerting inore control.

Although the proportion of plaintiffs who responded that they would sue again is very high for all elements of the surveyed population, there were some marginal differences. Ninety percent of elected officials and candidates for public office would sue again, even though, for this group, the incidence of judicial success was the lowest, and the existence of economic rather than reputational injury was sinall. For the otlier categories, the percentage of plaintiffs who said that they would sue again is as follows: public employees, $88 \%$; white collar employees, $78 \%$; business proprietors, $89 \%$; and professionals, $89 \%$.

Furtlier analysis of the composition of plaintiffs who responded that they would sue again if faced with a similar situation reveals interesting insiglits into both the litigation process and plaintiff motivation. Of the plaintiffs who lost in litigation, $84 \%$ said that they would sue again. Fifty-1nine percent would do so witlout changing lawyers or playing a more active role in the hitigation, $18 \%$ would get a better lawyer, and $7 \%$ would exert more control. Sixteen percent of the plamtiffs would either "not sue" (7\%) or "pursue nonlitigation alternatives" (9\%).

Separating these responses for losing plaintiffs who thouglit the suit accomplislied something and those who thought it accomplislied notling reveals the level of plamtiff dissatisfaction with counsel. Eighty-six percent of the plaintiffs who thought the suit accoinplished sometling responded that they would sue again. Only $11 \%$ of these plaintiffs would get a better lawyer or exert more control in a second suit; $75 \%$ specifically stated that they would sue witli the same lawyer. But, amazingly, even plaintiffs who tliought the suit accomplislied notling said that they would sue again $79 \%$ of the time. Only $39 \%$, howvever, would do so without cliange of lawyer or without exerting greater control; 29\% would sue again only after liiring a better lavver, and $11 \%$ would exert more control in the suit. Thus, while all plaintiff groups responded that they would sue again in the vast majority of cases, most of the plaintiffs who thouglit that their suit accomplished notling expressed dissatisfaction witl their lawyers or witl the course of litigation. These plaintiffs 
would therefore change lawyers or play a more active role in a second action.

Those who would change lawyers or exert more control prior to suit largely appear to be the private plaintiffs, who suffer the greatest financial harm from the alleged libel and who exhibit the greatest frustration toward the legal process. ${ }^{22}$ Eighty-nine percent of the individual plaintiffs classified as public figures or public officials and $84 \%$ of the private individuals responded that they would sue again. However, only $12 \%$ of public plaintiffs would get another lawyer $(8 \%)$ or exert more control (4\%); $77 \%$ would sue agam without any change in representation. By contrast, only $56 \%$ of the private plaintiffs would sue again without changing lawyers. Instead, $20 \%$ would change lawyers, and an additional $8 \%$ would exert more control.

Similarly, $90 \%$ of the elected officials or candidates for office responded that they would sue again if faced with the same situation. Ouly $15 \%$ would do so after replacing counsel or exerting more control over the suit. In stark contrast, while $78 \%$ of the plaintiffs classified as white collar employees said that they would sue again, only $33 \%$ would do so without some change in representation. Nearly $45 \%$ of these plaintiffs would either change lawyers $(11 \%)$ or exert more control (33\%).

Finally, $88 \%$ of the plamtiffs with contingency-fee arrangements indicated that they would sue again, and $71 \%$ would do so without change in representation or exertion of greater control over the suit. For plaintiffs with liourly fee arrangements, $80 \%$ said that they would sue again, but only $40 \%$ would do so without change of representation. Instead, $27 \%$ would change lawyers, and $13 \%$ would exert more control. Interestingly, only $4 \%$ of the plaintiffs with contingency-fee arrangements indicated that they would not sue again, compared with $13 \%$ of those with hourly fee arrangements.

The plamtiffs' responses regarding whether they would sue again are not necessarily predictive of their resolve to employ suit in the future. Rather, the significance of the responses lies in what they suggest about the plaintiffs' objectives in suing. Generally, plaintiffs appear to believe that bringing suit achieves significant vindication and that no other means of obtaining or claiming vindication exists. Public plaintiffs, in particular, seem to view litigation as an acceptable form of responsecertainly more effective than a public statement denying the alleged libel-and an inexpensive one, as they experience the lowest litigation

22. The statistics in this and in the following paragraph are significant at roughly the 0.1 level of confidence. The relationships, while less statistically reliable than others discussed in this Article, follow consistent patterns and are supported by relationships among other variables. Moreover, the level of significance seems substantially to be a function of the number of separate categories coded for the responses, and the overlap among them. 
costs and the highest incidence of contingency arrangements. Such plaintiffs exhibit a remarkable degree of satisfaction with the way in which the litigation, and their lawyer, legitimated their claims of falsity. It appears that the private plamtiffs harbor the greatest frustration, both with the effectiveness of litigation in achieving their more frequently financial objectives and with their lawyers.

\section{Conclusion}

The general conclusion to be drawn froin these data seems clear. Private plaintiffs, for whom the legal obstacles to success are the lowest. ${ }^{23}$ are least likely to view hitigation as an attractive ineans of obtaining redress. These plaintiffs are most likely to experience significant economic harm from a hibel. They are also most dissatisfied with their lawyers, inost frustrated by the hitigation experience, and most likely to pay the bill. Private plaintiffs, in short, are directly and effectively discouraged by the rules and results of the legal system.

By contrast, while public plaintiffs face greater legal obstacles to recovery, and win less frequently than the private plaintiffs, they seem generally satisfied with their lawyers, significantly less frustrated by the hitigation process, and inore inclined to say that they would sue again. Their harm is inost often strictly reputational rather than economic, and they rarely pay significant lawyer fees. For them, the libel action is essentially a free good. They are not significantly affected by rules and results of the legal system, even though those rules are very inuch intended to discourage thein froin suing. ${ }^{24}$

There is an additional factor, however, that leads virtually all of the public plaintiffs and the overwhelming majority of private plaintiffs to say they would sue again. It is a perception that despite all its frustrations litigation is the ouly effective ineans of achieving a remedy for their reputational, as distimguished froin econoinic, harm. The act of sumg itself represents a public response denying the story, which legitimates the plaintiff's claim of falsity inore effectively than any other inethod. The delay in judicial decision, coupled with resolution on grounds of privilege rather than truth or falsity, assures plaintiffs a face-saving explanation for the almost inevitable inedia victory. The risk that litigation will confirm the truth of the challenged stateinent is shight.

23. See Gertz v. Robert Welch, Inc., 418 U.S. 323 (1974).

24. The clear impact of the actual malice privilege is to discourage suits by public figures and to facilitate robust speech on public issues. See New York Times Co. v. Sullivan, 376 U.S. 254 (1964). Public plaintiffs with legitimate claims of falsity and defamation are discouraged from suing unless they can establish calculated falsehood or calculated indifference to truth. Id. Neither of these issues has any necessary bearing on the questions of falsity and reputational harm, and both issues foreclose many, if not most, legitimate plaintiff claims of falsity and damage. 
For most libel plaintiffs, the act of suing achieves reputational objectives. The fact that roughly $90 \%$ of the losing plaintiffs responded that they would sue again if faced with a similar situation confirms this. In actual practice, therefore, the hibel action serves very different purposes than those set for it by the legal system, and apparently serves those other purposes effectively. Ironically, the villain in the act, if there is one, may be the very constitutional privileges designed to discourage suit and protect the press.

\section{II}

\section{Alternative Nonjudicial Processes: Plaintiff}

\section{ATTITUDES AND OBJECTIVES}

The overwhelming majority of the libel plaintiffs expressed interest in nonlitigation alternatives for resolution of their libel suits. Seventy percent of the plamtiffs responded that they would consider such an alternative, and an additional $13 \%$ mdicated that they would do so with certain qualifications. Only $14 \%$ expressed no interest in alternative processes, and $3 \%$ were uncertain. The significance of these responses must be analyzed in hight of the plaintiffs' equally overwhelming response that they would sue again if faced with a similar situation. This analysis confirms the view that most plaintiffs focus their concern on falsity, that their chief goal is setting the record straight, and that filing the suit partly achieves this goal.

\section{A. Under What Circumstances Would the Plaintiffs Avoid Litigation?}

Most of the plaintiffs, although dissatisfied with their litigation experience, simply did not consider alternative nonjudicial processes in advance of suing. In part, this is because their lawyers did not raise the subject. Sixty percent of the responding plaintiffs' lawyers did not discuss alternatives to litigation. In large part, this was because few such alternatives exist, and even fewer would serve satisfactorily to achieve the plaintiffs' goals. For example, of those plaintiff lawyers who did discuss nonlitigation alternatives, half discussed settlement, and one-third told their clients that suit was unnecessary. Rather than present nonlitigation as a viable alternative, $72 \%$ of the lawyers indicated that the chance of success in the lawsuit was $50 \%$ or better and that the chance of settlement was slim. Because so many of the plaintiffs responded that they would sue if agam faced with a similar situation, the logical conclusion is that those plaintiffs whose lawyers did suggest alternative nonjudicial processes saw the alternatives as unsatisfactory means to restore their reputations when compared with litigation. ${ }^{25}$

25. Most of the plaintiffs and lawyers we interviewed had, in fact, brought suit. It is likely that 
This conclusion is confirmed by the plaintiffs' responses concerning why they would consider a nonlitigation alternative. We asked plaintiffs if they would consider a nonlitigation alternative that would have four key elements: (1) proinptness; (2) fairness; (3) determination of the accuracy of the challenged statement; and (4) publication of the outcome. We then asked those who would consider such an alternative, why they would consider the alternative. Those responses appear in Table Four.

\begin{tabular}{lcr}
\multicolumn{3}{c}{ TaBle Four } \\
WhY Avold LITIGATION? \\
Conditions & (Number) & \\
\hline Avoid Suit & $(32)$ & Percent \\
Reduce Cost \& Time & $(15)$ & $24 \%$ \\
More Just Outcome & $(32)$ & $11 \%$ \\
Outcome Publicized & $(36)$ & $24 \%$ \\
Damages Available & $(14)$ & $27 \%$ \\
Other & $(5)$ & $10 \%$ \\
$\quad$ Total & $(134)$ & $4 \%$ \\
& & $100 \%$
\end{tabular}

The features of the alternative process in which plaintiffs' expressed interest are instructive of the reasons for suit and the prime objectives libel plaintiffs seek to accomplish. Those who would consider a nonlitigation alternative explained their interest specifically in terms of avoiding suit (24\%), reducing cost and time (11\%), achieving a inore just outcome (24\%), and having that outcome made public (27\%). Only $10 \%$ expressed a need for money dainages. Moreover, of the $13 \%$ of the plaintiffs who quatified their interest in nonlitigation alternatives, less than half (42\%) would require the availability of money damages, and $37 \%$ conditioned their interest in terms of publication of the outcome.

While the plaintiffs may not have had a clear and specific picture of the alternative nonjudicial processes available to them, the plaintiffs did express through their open-ended responses an interest in nonlitigation alternatives containing certain general elements. Thirty-two plaintiffs (24\%) would employ a nonlitigation alternative in order to avoid suit. This response at first inay seem difficult to reconcile with the overwhelming number of plaintiffs who responded that they would sue again if faced with the same situation. The discrepancy is probably the result of the

many plaintiffs who did not sue employed alternatives, settled, or dropped the claim with or without negotiation. Estimates of this population vary, but it seems substantial, perhaps five to ten times the population of plaintifis who sue, judging from information provided by insurance files, media defendants, and plaintiff lawyers. A discussion of this population is beyond the scope of this Article. It should be noted, however, that only one news council (a formal adjudicative nonjudicial process) exists today (Minnesota), and that the rate of settlement, judging from the insurance cases we have examined, may be as high as $25 \%$. 
plaintiffs' beliefs that there are few viable alternatives to suit. When asked if they would be interested in a viable alternative, even those who would sue again in the saine situation responded that they would consider a nonlitigation alternative. For these plaintiffs, the lawsuit itself seems to have served little purpose.

Another fifteen plaintiffs $(11 \%)$ stated that reducing cost and time was a precondition to a nonlitigation alternative, and thirty-two (24\%) would have considered a nonlitigation alternative if it would produce a more just outcome. These two responses reflect significant interests in making the nonlitigation alternatives more prompt and fair, qualities that plaintiffs obviously find missing from litigation. Along with the interest in avoiding suit, these three groups (seventy-nine plaintiffs, or 57\%) represent a large residue of dissatisfaction specifically directed at the litigation process. In most cases, plaintiffs would prefer a ineaningful alternative to litigation as a process for resolution of their dispute.

Thirty-six plaintiffs, or $27 \%$, responded that they would have considered alternative nonjudicial processes if the outcoine were publicized. It is highly likely that more plaintiffs than these thirty-six would require publicity as a precondition because the question itself described the alternative as involving a "public" determination. Because over eighty-five percent of the plaintiffs who did respond eventually lost their lawsuits, the "outcome publicized" precondition probably reflects these plaintiffs' imterest in restoring their reputations by some public proclamation. In any case, the data suggest that there remains a significant group of plaintiffs who, if given the opportunity for a meaningful publication of the outcoine, would not have cliosen litigation.

Finally, fourteen plaintiffs, comprising $10 \%$ of those responding, conditioned alternative nonjudicial processes on the availability of damages. These plaintiffs consist disproportionately of private individuals who appear to have suffered actual financial damage to their businesses or in their professions. Although the legal system provides access for these plaintiffs to bring their hibel claims, they found that their libel suits did not reinedy their economic harm. Coupled with the fact that these plaintiffs are in most cases paying their lawyers' fees, it should not be surprising that for them the availability of damages is a significant precondition to any nonlitigation alternative.

Although for $83 \%$ of the plaintiffs nonlitigation could be a viable alternative, a small group of twenty-three plaintiffs comprising $13 \%$ of all plaintiffs, would choose litigation even over a nonlitigation alternative that provided for money damages. A sinall proportion of this group consists of plaintiffs who won or settled and therefore inight be expected to prefer the judicial process.

The pattern that emerges from the responses is that plaintiffs over- 
whelmingly express interest in alternatives to litigation. The key characteristics of the alternative are promptness, fairness, resolution of the underlying dispute concerning falsity, and publication of the result. Notably, inoney seens to play a distinctly secondary role in the plaintiffs' judgments about alternatives.

\section{B. Which Plaintiffs Would Consider Nonlitigation Alternatives?}

Analysis of the plaintiffs who would consider nonlitigation alternatives reveals fairly coinplex relationships. Many of the relationships concern the plaintiffs' actions prior to suit.

There seems to be a relationship between the media response to the plaintiffs' initial contact and the circumstances in which plaintiffs would consider nonlitigation alternatives. It appears that the inore negative the inedia response, the inore likely the plaintiff is to condition alternative nonjudicial processes on a specific, affirmative act by the media defendant-that is, eitler publicizing the outcome or giving the plaintiff money damages. For exainple, when the inedia refused the plaintiff's demands or repeated the story uncorrected, $47 \%$ of the plaintiffs placed specific conditions on their interest im nonlitigation alternatives. ${ }^{26}$ By contrast, when the inedia retracted, corrected, apologized, or did not repeat the story, only $30 \%$ expressly conditioned their interest. ${ }^{27}$

These results suggest a complex dynamic between libel plaintiffs and media defendants. At the very least it suggests that the more responsive the inedia is to a plaintiff's contacts, the inore likely the plaintiff will be receptive to alternative nonjudicial processes. This hypothesis is consistent witli the conclusion inentioned previously ${ }^{28}$ that media response was the most pervasive factor contributing to the plaintiffs' decisions and actions.

The data also suggest that the timing of the plaintiffs' decision to litigate had an important impact on their receptivity to nonlitigation alternatives. Most of the plaintiffs who said that they decided to sue after seemg a lawyer expressed an interest in a fairer, inore just, and less timeconsuming alternative to litigation. Of the sixty plaintiffs who decided to sue after seeing their lawyers, fifty-three (88.3\%) expressed interest in a nonlitigation alternative. Only ten of these plaintiffs (19\%) would liave conditioned their interest on publication of the outcoine, while only one plaintiff (2\%) would have made the availability of inoney damages a prerequisite. On the other hand, plaintiffs who said that they decided to sue

26. Twenty-three plaintiffs (31\%) wanted the outcome publicized and 12 plaintiffs (16\%) wanted money damages.

27. Six plaintiffs (26\%) demanded that the outcome of the nonlitigation alternative be publicized, and only one (4\%) conditioned nonlitigation on receiving money damages.

28. See supra text accompanying note 11 . 
before seeing their lawyers were primarily interested in nonlitigation alternatives with a specific affirmative act as a precondition. Of the seventy-nine plaintiffs who decided to sue before seeing their lawyers, sixtyfive, or $82 \%$, would consider nonlitigation alternatives. Twenty-one $(32 \%)$ of the sixty-five plaintiffs would consider nonlitigation only if the outcoine were publicized, and eleven (17\%) would do so only if inoney damages were available.

Most of the plaintiffs who decided to sue before seeing their lawyers were public plaintiffs. It is not surprising, in light of this, that the largest group in the population of plaintiffs who decided to sue before seeing their lawyers and who would have considered nonlitigation as an alternative were pubhic plaintiffs who wanted the outcome publicized. Private plaintiffs, however, also conditioned nonlitigation alternatives, though largely in terms of availability of dainages. ${ }^{29}$ Plaintiff status, therefore, may not fully explain why the timing of the decision to sue engenders the different receptivity to nonlitigation alternatives. An additional explanation inay be that the involveinent of lawyers before the plaintiff decided to sue liad a leavening influence on the plaintiff' objectives in litigation, which influenced their receptivity to nonlitigation alternatives. ${ }^{30}$

29. See supra text following note 25 .

30. Another factor related to the plaintiff's receptivity to nonjudicial processes is the plaintiff's education.

TABLE FIVE

The Plaintiffs' Education and INTEREst in Nonlitigation Alternatives

\begin{tabular}{|c|c|c|c|}
\hline & $\begin{array}{l}\text { HIGH SCHOOL } \\
\text { OR BELOW }\end{array}$ & $\begin{array}{l}\text { Some College } \\
\text { OR College } \\
\text { Graduate }\end{array}$ & $\begin{array}{c}\text { Graduate or } \\
\text { Professional } \\
\text { DEgREE } \\
\end{array}$ \\
\hline Prompt, FAIR, INEXPENSIVE & $\begin{array}{l}18 \\
67 \%\end{array}$ & $\begin{array}{l}30 \\
71 \%\end{array}$ & $\begin{array}{l}20 \\
48 \%\end{array}$ \\
\hline Outcome Publicized & $\begin{array}{c}7 \\
26 \%\end{array}$ & $\begin{array}{l}11 \\
26 \%\end{array}$ & $\begin{array}{l}14 \\
33 \%\end{array}$ \\
\hline MONEY DAMAGES AVAILABLE & $\begin{array}{l}2 \\
7 \%\end{array}$ & $\begin{array}{l}1 \\
1 \%\end{array}$ & $\begin{array}{c}8 \\
19 \%\end{array}$ \\
\hline
\end{tabular}

SIGNIF. @ .0048

The largest group of the libel plaintiffs (42 of 111 plaintiffs or $38 \%$ ) have graduate or professional degrees. Of these 42 plaintiffs, the majority (22, or $52 \%$ ) condition their acceptance of nonlitigation alternatives on some affirmative act (money or publication) by the defendant. These numbers reflect what we would expect to be the interests of both well-to-do professionals, who may have suffered dramatic economic losses, and well-educated public plaintiffs whose primary loss can be resolved by some public notice that would restore their reputations. At the other end of the education scale, those plaintiffs with only a high school diploma or less appear less inclined to condition nonlitigation alternatives on a specific remedy of publication or damages. Seven plaintiffs (26\%) would consider nonjudicial processes if the outcome would have been publicized, while two (7\%) would consider them if money damages had been available. Nearly two-thirds would require neither as a precondition. Those plaintiffs who have had some college or have graduated from college followed the same pattern.

Perhaps the most significant comparisons across the three education classifications arc the avail- 


\section{The Plaintiffs' Objectives and the Nonlitigation Alternative}

The reasons why plaintiffs sued are the most important means of understanding the plaintiffs' willingness to accept nonlitigation alternatives. A comparison of the two factors appears in Table Six.

\section{TABLE SIX \\ Why Did the Plaintiff SUe and Under What \\ Circumstances Would the Plaintiff Avoid \\ Litigation}

\begin{tabular}{|c|c|c|c|c|}
\hline \multirow[b]{2}{*}{$\begin{array}{l}\text { Why Avoid } \\
\text { Litigation }\end{array}$} & \multicolumn{3}{|c|}{ Why Plaintiff Sued } & \multirow[b]{2}{*}{$\begin{array}{l}\text { Deter } \\
\text { Further }\end{array}$} \\
\hline & $\begin{array}{l}\text { Restore } \\
\text { Reputation }\end{array}$ & $\begin{array}{l}\text { Win Money } \\
\text { Dainages }\end{array}$ & $\begin{array}{l}\text { Punish and } \\
\text { Vengeance }\end{array}$ & \\
\hline Avoid Suit & 11 & 4 & 8 & 8 \\
\hline col. \% & $28 \%$ & $17 \%$ & $20 \%$ & $33 \%$ \\
\hline Reduce Cost & 3 & 0 & 5 & 7 \\
\hline and Tine & $7 \%$ & $0 \%$ & $12 \%$ & $29 \%$ \\
\hline More Just & 8 & 6 & 11 & 7 \\
\hline Outcoine & $21 \%$ & $26 \%$ & $27 \%$ & $29 \%$ \\
\hline Outcome & 16 & 4 & 14 & 1 \\
\hline Publicized & $41 \%$ & $17 \%$ & $34 \%$ & $4 \%$ \\
\hline Money Damages & 1 & 9 & 3 & 1 \\
\hline Available & $3 \%$ & $39 \%$ & $7 \%$ & $4 \%$ \\
\hline & Sign & if. @ . .00001 & & \\
\hline
\end{tabular}

Of those plaintiffs who said they sued to restore their reputations, eleven $(28 \%)$ would have accepted nonjudicial alternatives to avoid the lawsuits, three (7\%) would have required a reduction of cost and tine, eight plaintiffs $(21 \%)$ would have wanted more just outcomes, and sixteen (41\%) would have made publication of the outcome a prerequisite. For these plaintiffs, money damages were rarely a precondition. Instead, nonlitigation alternatives that avoided suit and involved a published outcome could have satisfied their interest in restoring their reputation.

Of the twenty-three plaintiffs who reported that they sued to obtain money damages, only nine, or $39 \%$, would condition use of a nonjudicial alternative on the availability of money damages. This result is interest-

ability of damages and the interest in reducing cost and time. Nineteen percent of the graduate or professional plaintiffs expect money, compared with only $7 \%$ of the high school plaintiffs and $1 \%$ of the college plaintiffs. The graduate and professional plaintiffs who would consider nonlitigation alternatives were much more preoccupied with their economic losses than were the other two classes of plaintiffs. On the other hand, it appears that the high school or college educated plaintiffs would have accepted nonlitigation if it were cheaper. Eleven percent of the high school plaintiffs and $21 \%$ of the college plaintiffs, compared with only $2 \%$ of the graduate plaintiffs, mentioned reduced cost and time as the most important factor. 
ing; one would have expected inore plaintiffs in this group to have chosen this condition. The other fourteen plaintiffs reported that they would, at least in retrospect, have different objectives in the nonlitigation situation than they had had in their lawsuits.

Of equal interest is the fact that of the forty-one plaintiffs who sued to punish the inedia, fourteen, or $34 \%$, would require that the outcome be pubhicized. Only three of these forty-one plaintiffs (7\%) would have required the availability of inoney dainages. These statistics tend to confirm the view that inedia interaction with the plaintiff heavily influences punishment as a reason for suit, but the presence of financial harm to the plaintiff does not.

Indeed, the vast inajority of plaintiffs who sued to punish the media appear actually to have had surprisingly bemgn objectives, in view of their interest in nonlitigation alternatives. Even those plaintiffs who initially sued with perhaps the nost vindictive of motives were receptive to nonlitigation alternatives. This inay highlight a fundamental problem with current libel hitigation. By forcing the parties to define the dispute as a conflict between press irresponsibility and free expression, the judicial process niay create inore controversy than it resolves.

Finally, those plaintiffs whose principal reported objective in suing was to protect their reputation by deterring further publication seemed reniarkably disniterested in either inoney or pubhication. In view of their hinited stated objective, their interest in an alternative that efficiently achieves that objective is understandable. What is surprising about their responses is that such plaintiffs are mterested in alternatives to litigation at all because filing a lawsuit is likely to be a fairly effective deterrent.

\section{CONCLUSION}

The plaintiffs' responsiveness to alternative ways of resolving their disputes suggests that the coinplex calculus of plaintiff notives permeated all facets of their lawsuits, including their receptivity to nonjudicial alternatives. Of course, the calculus inust take into account the plaintiffs' considerable uncertainty about what the nonlitigation alternatives would have been. We cannot be certain whether they conceived the alternative as a inediated nonjudicial result or as sonie nirvana where all the objectives they set for their libel suits would be fulfilled. Obviously, what constitutes a meaningful alternative would have to be as individual as the lawsuits thenselves. Notwithstanding this ambiguity, however, we can cautiously advance several observations.

For many plaintiffs, the chief interest is in the underlying falsity of the challenged statenient. They desire a prompt and fair process for publicly setting the record straight. Only a small portion of plaintiffs 
expressed no interest in alternatives. ${ }^{31}$ The plaintiff's' responses reflect a set of objectives that are often benign and constructive, but which are frustrated by the litigation process and legal rules. The view of libel plaintiffs as persons with no confldence in their claim who inanipulate the legal process for personal ends seems greatly overbroad in light of the cumulative weight of these responses. ${ }^{32}$

Rather than suing for improper or manipulative reasons, nost plaintiffs seem to resort to hitigation as a means of self-help and legitimation of their claim. The fact that the legal process encourages use of higation as a self-help instrument through its delay, ${ }^{33}$ relative inexpensiveness, ${ }^{34}$ and low risk of loss on the inerits of the dispute, ${ }^{35}$ and the fact that plaintiffs may eniploy litigation for these very reasons, does not derogate their motives. Nor does the fact that some plaintiffs use the legal system to pursue a meritless claim discredit the motives of all plaintiffs. Rather, these facts only serve to confirm the conclusion that inost plaintiffs sue for the simple reason that they have no effective alternative for redressing reputational harm. The judicial systein, rather than plaintiffs, is responsible for this state of affairs.

The plaintiffs' responses that they would sue again if faced with the same situation do not overshadow their interest $\dot{n} 1$ alternative nonjudicial

31. Fourteen percent expressed no interest in alternatives, and $10 \%$ would precondition their interest in an alternative on the availability of money damages. Moreover, more than half of these plaintiffs won in litigation, settled, or experienced financial harm compensable only through money damages. Public officials exhibit the greatest disinterest in nonlitigation alternatives, although twothirds of this group would consider such alternatives. The willingness of the other third of this group to sue again even in the face of an alternative tends to confirm the conclusion that, for public officials in particular, the act of suing itself achieves public vindication. Very few plaintiffs seem to have based their disinterest in alternatives on a desire to punish the defendant through litigation. While the plaintiff responses are self-reported and therefore possibly self-serving (despite assurances of confidentiality), the magnitude of responses, their internal consistency, the patterns of respouses by plaintiff groupings, and their general confirmation by the media defendants, suggest that the underlying objectives refiected in the responses are real. See supra note 12.

32. The fact that the majority of cases appeared insubstantial when judged by standards of material falsity and reputational harm does not undermine this conclusion, for "insubstantial" defamation claims often involve statements that are incorrect or incomplete and that plaintiffs genuinely perceived as causing emotional harm. See Bezanson, supra note 7, at 230 (discussing the incidence of probable and actual falsity in adjudicated cases, as well as the incidence of nonsubstantial claims).

33. The average length of suit was four years.

34. The average cost of litigation to plaintiffs was about $\$ 7,000$. Most plaintiffs payed less than $\$ 5,000$, and many payed nothing.

35. Largely because of the constitutional privileges, which focus on fault, the courts infrequently address actual truth or falsity of the allegedly libelous publication. Judicial resolution occured at the pretrial stage on grounds of privilege in roughly three-quarters of the cases. See Bezanson, supra note 7, at 230-31. This may change somewhat in light of the Supreme Court decision in Philadelphia Newspapers, Inc. v. Hepps, 106 S.Ct. 1558 (1986), although the fault emphasis will likely continue to dominate adjudication. 
processes. Again, these responses may reflect little more than the fact that nonlitigation alternatives are essentially nonexistent today.

The plaintiffs' initial contacts with the media influenced the kind of preconditions they would place on nontitigation processes. The more negative the media response to the plaintiff, the harsher the alternative the plaintiff demanded.

The plaintiffs' objectives changed dramatically from the time their suits were initiated to the point at which we asked them about alternatives to litigation. Importantly, a number of plamtiffs who liad set out to obtain money or to punish the media in their lawsuits chose less antagomistic objectives in a nonjudicial setting. Because these less antagonistic objectives were expressed retrospectively, we cannot conclude that plaintiffs who have not experienced a libel suit would be equally receptive. The next phase of the Iowa Libel Research Project will gatlier information on this issue when we test receptivity to specific nonlitigation processes.

Finally, while no one can ascertain today the effectiveness of nonlitigation alternatives, there is reason to believe that problems do exist within the structure of the libel litigation process itself, and that some of these structural problems anay be soluble notwithstanding development of alternative processes. Each of the libel law ironies I mentioned at the beginning of this Article may arise out of the fact that most plaintiffs appear to pursue and aclieve objectives through a libel suit that bear strikingly little relationslip to the objectives set by the legal system. Ascertainment of fault and iniposition of money dannages dominate the legal process. By contrast, effective response to alleged falsity, emotional relief, and vindication of reputation chiefly appear to motivate most plaintiffs. For tliese plaintiffs, the act of suing, independent of the ultimate judicial resolution, aclieves these objectives in significant measure. Indeed, bringing suit may be tlie only effective form of response available today. 